\title{
Balé dramático e literatura em diálogo: uma análise da obra infantojuvenil O lago dos cisnes, adaptada por Lee Ji Yoeng e ilustrada por Gabriel Pacheco
}

\author{
Eliane Aparecida Galvão Ribeiro Ferreira \\ Universidade Estadual Paulista "Júlio de Mesquita Filho" (UNESP), Assis, São Paulo, Brasil \\ eliane@assis.unesp.br \\ Cláudia Valéria Penavel Binato \\ Universidade Estadual Paulista "Júlio de Mesquita Filho" (UNESP), Assis, São Paulo, Brasil \\ claudiapbinato@uol.com.br
}

DOI: http://dx.doi.org/10.21165/el.v46i3.1602

\begin{abstract}
Resumo
Este texto tem por objetivo apresentar uma análise da obra $O$ lago dos cisnes, adaptada por Lee Ji Yoeng (2012) e ilustrada por Gabriel Pacheco, a partir do balé clássico homônimo composto por Pyotr Ilyich Tchaikovsky (1840-1893), com libreto de Vladimir Begitchev e Vasily Geltzer. Esta obra compõe a coleção Música clássica em cena, da editora FTD, que visa a apresentar ao público infantil e juvenil histórias de importantes libretos considerados clássicos no campo musical. Mais especificamente, pretende-se neste texto verificar, a partir dos princípios de Bakhtin (2000), como se efetiva a dialogia entre o balé dramático de Tchaikovsky e a obra adaptada de Lee Ji Yoeng. Para a consecução dos objetivos, pretende-se apresentar uma reflexão fundamentada pela Estética da Recepção acerca do que propicia o prazer na leitura e quais elementos determinam o papel do leitor implícito. Constrói-se, neste texto, a hipótese de que a estratégia de Lee Ji Yoeng de resgatar um balé clássico e adaptá-lo sob a forma de narrativa ilustrada para o leitor iniciante, tanto lhe faculta contato com um texto atraente e ricamente ilustrado que enriquecerá seu imaginário, quanto amplia seus conhecimentos, por meio do resgate da memória cultural. A apropriação de uma produção cultural clássica, mas adaptada à linguagem narrativa e direcionada ao leitor em formação, pode atuar como fator de valoração da identidade deste leitor. Por meio dela, ele é capaz de elevar sua autoestima, pois percebe que é considerado como receptor de uma produção, ao mesmo tempo em que se reconhece como herdeiro de um patrimônio cultural tradicional.
\end{abstract}

Palavras-chave: balé; Estética da Recepção; cultura clássica.

Dramatic ballet and literature in dialogue: an analysis of the children and youth work $O$ lago dos cisnes, adapted by Lee Ji Yoeng and illustrated by Gabriel Pacheco

\begin{abstract}
This study intends to present an analysis of the work of $O$ lago dos cisnes, adapted by Lee $\mathrm{Ji}$ Yoeng (2012) and illustrated by Gabriel Pacheco, from the homonymous classical ballet composed by Pyotr Ilyich Tchaikovsky (1840-1893), with libretto by Vladimir Begitchev and Vasily Geltzer. This work composes the Música Clássica em cena collection [Classical Music onstage], by the FTD publishing house, which aims to present to young people and children stories of important leaflets regarded as classics in the music field. More specifically, we intend to verify this text from the principles of Bakhtin (2005) as the effective dialogy between the dramatic ballet of Tchaikovsky and the work adapted by Lee Ji Yoeng. For achieving the goals, we intend to present a reflection based on the Reception Aesthetics about what provides the pleasure in reading and which elements determine the role of the implied reader. In this text, we elaborated hypothesis
\end{abstract}


that the strategy of Lee Ji Yoeng of rescuing a classical ballet and adapt it in the form of illustrated narrative for beginner readers, as far as provides the readers with contact with an attractive and lavishly illustrated text that will enhance their imagination, as it expands their knowledge through the rescue of cultural memory. The appropriation of a classic cultural production, but adapted to the narrative language and directed to developing reader can act as a valuation factor of the identity of this reader. Through it, he is able to elevate his self-esteem, because he realizes that he is considered as a receiver of a production, while he is recognized as the heir of a traditional cultural patrimony.

Keywords: ballet; Aesthetics of Reception; classical culture.

\section{Introdução}

O lago dos cisnes (2012), adaptado pela escritora coreana Lee Ji Yoeng (1957-), ilustrado por Gabriel Pacheco e traduzido por Heloísa Prieto, a partir do balé clássico homônimo composto por Pyotr Ilyich Tchaikovsky (1840-1893), inspirado em uma lenda germânica, com libreto de Vladimir Begitchev e Vasily Geltzer, apresenta seu enredo sob a forma de um conto de fadas ilustrado em cores. Esta obra compõe a coleção Música clássica em cena, da editora FTD, que visa a apresentar ao público infantojuvenil histórias de libretos clássicos no campo musical.

Ao término do livro, sob o título "Sobre o balé O lago dos cisnes" (YOENG, 2012), encontram-se anexos que narram, por meio de fotos e desenhos ilustrativos, tanto a biografia de Tchaikovsky, quanto a história na qual se inspirou para produzir esse balé. No anexo "As peças musicais de O lago dos cisnes" (YOENG, 2012), elucida-se que, das 36 peças musicais da apresentação original, as seis mais apreciadas pelo público se tornaram sequências coreografadas em quatro atos, narrando a história de Odete e Sigfried, respectivamente: Ato $I$ - Valsa ${ }^{\circ}$ 2; Ato II - Cena n ${ }^{\circ}$ 1, Dança dos Pequenos Cisnes e Dança dos Cisnes; Ato III - Dança Húngara no 20 e, por último, Ato IV - Cena Final $n^{\circ} 29$. O penúltimo anexo, intitulado "Para saber mais" (YOENG, 2012), recorre à história do balé, expondo trajes, sapatilhas e gestos próprios para a compreensão de sua arte. As biografias da adaptadora Lee Ji Yoeng, do ilustrador Gabriel Pacheco, e da tradutora Heloisa Prieto, dispostas ao final do livro (YOENG, 2012), conferem-lhes autoridade e ressaltam sua formação cultural. Um CD, com as seis composições, disposto no encarte, compõe o último anexo.

De acordo com a ficha técnica do livro, fornecida pela sua editora, trata-se de uma história a ser explorada a partir do quinto ano do Ensino Fundamental, o que justifica sua classificação como infantojuvenil, destinada ao pré-adolescente ou adolescente, a partir de 10 ou 11 anos de idade (FTD EDUCAÇÃO, 2016). Apesar dessa caracterização editorial, o livro, em 2013, recebeu o Prêmio "Altamente Recomendável" da FNLIJ Fundação Nacional do Livro Infantil e Juvenil, na categoria "Tradução/Adaptação Criança"; em 2015, foi selecionado para o Acervo 2 do PNAIC - Pacto Nacional pela Alfabetização na Idade Certa (DIÁRIO OFICIAL DA UNIÃO, 2016), composto por livros ilustrados ou de imagem, na categoria 3, destinados ao terceiro ano do Ensino Fundamental, série em que se encontram crianças entre oito e nove anos de idade.

Ambas classificações situam-no, então, como obra infantil, talvez, pela dialogia que estabelece com os contos de fadas e vem expressa na clássica fórmula de abertura "Era uma vez, em um reino muito distante, um príncipe chamado Siegfried e a rainha, 
sua mãe.” (YOENG, 2012, p. 6) -, na temporalidade, que instaura a sugestão do onírico, e na eleição de heróis provenientes da realeza, oprimidos por um maligno feiticeiro.

O PNAIC, lançado pelo Ministério da Educação (MEC), com a participação articulada entre governo federal, governos estaduais e municipais, e do Distrito Federal, visa à alfabetização e ao letramento literário de crianças até oito anos de idade (PACTO NACIONAL PELA ALFABETIZAÇÃO NA IDADE CERTA, 2016). Para tanto, mobiliza recursos que revertem em implementação de sistemas de avaliação, gestão e monitoramento, e por meio do PNLD - Programa Nacional do Livro Didático, bem como do PNBE - Programa Nacional Biblioteca da Escola, distribui materiais didáticos e obras literárias para salas de aula, salas de leitura e bibliotecas. Essa distribuição desenvolve-se em parceria com o Fundo Nacional de Desenvolvimento da Educação (FNDE) e a Secretaria de Educação Básica (SEB/MEC). As obras literárias que compõem seus três acervos, destinados ao primeiro, segundo e terceiro anos do Ensino Fundamental, resultam de seleção e avaliação pedagógica. Objetiva-se com esses livros ofertar aos docentes e às crianças um material rico para fruição, apreciação da leitura e formação do gosto literário.

Conforme as Diretrizes Curriculares Nacionais para o Ensino Fundamental de nove anos (Resolução CNE n ${ }^{\circ}$ 7/2010) (PORTAL MEC, 2016), os três anos iniciais do ensino fundamental devem assegurar, por meio de uma abordagem interdisciplinar, a alfabetização e o letramento, bem como o "[...] desenvolvimento das diversas formas de expressão, incluindo o aprendizado da Língua Portuguesa, da Literatura, da Música e demais Artes e da Educação Física, assim como o aprendizado da Matemática, da Ciência, da História e da Geografia" (LITERATURA NA HORA CERTA: guia 3, 2015, p. 6). Justifica-se, então, a inclusão no Acervo 2 da obra $O$ lago dos cisnes (2012) que, de caráter interdisciplinar, dialoga com as artes plásticas, a dança, os contos de fadas, o teatro e a música.

A eleição dessa obra como objeto de estudo deveu-se a dois motivos. O primeiro, pelo seu enredo híbrido, o qual pode ser cativante para o pequeno e jovem leitor, pois dialoga com o teatro dramático, o balé e o conto de fadas. Desse modo, a obra torna válido o pressuposto de Mikhail Bakhtin (2000) de que todo enunciado se constitui por meio de outros. Para este estudioso, “[...] o objeto do discurso de um locutor, [...], não é objeto do discurso pela primeira vez neste enunciado, e este locutor não é o primeiro a falar dele. $\mathrm{O}$ objeto, por assim dizer, já foi falado, controvertido, esclarecido e julgado de diversas maneiras [...]" (BAKHTIN, 2000, p. 319). Por este viés, o objeto do discurso é ponto de intersecção em que se encontram diferentes opiniões e relações de sentido diversas.

O segundo motivo deveu-se à relação estética de interação e colaboração que se estabelece entre texto musical, verbal e imagético, estes dois últimos dispostos na folha dupla. Conforme Linden (2011), nessa folha, tanto o texto verbal, quanto a imagem se dispõem livremente, possibilitando aos criadores um campo fundamental e privilegiado de registro e de expressão. A representação nessa folha sugere uma leitura que considera a abertura do livro como suporte expressivo em si, capaz de escapar ao movimento de encadear páginas durante a leitura. Justamente, por isto, constrói-se neste texto, a partir dos pressupostos teóricos da Estética da Recepção, na acepção de Wolfgang Iser (1999) e de Hans Robert Jauss (1994), a hipótese de que a obra O lago dos cisnes (2012) favorece a ruptura com conceitos prévios do leitor sobre modos de ler, ampliando seus horizontes 
de expectativas e facultando-lhe discernimento de mundo e posicionamento perante a realidade.

O livro de Yoeng (2012), por supor como receptor o leitor em formação, apresenta uma estrutura de apelo que, para Iser (1996, p. 73), projeta um leitor implícito, ou seja, essa estrutura "[...] antecipa a presença do receptor". Pela leitura da obra, nota-se que prevê um leitor implícito formado globalmente pela sensibilização, ou seja, pela estética da sensibilidade. Nessa estrutura, os vazios são apresentados a seus leitores, para que, pela leitura, descubram suas próprias projeções. Esses vazios "[...] forçam o leitor a se desfazer de parte de suas expectativas habituais" para que chegue à interpretação (ISER, 1999, p. 129). De acordo com Jauss (1994, p. 31), a distância estética favorece a mudança de horizonte de expectativa, pois "[...] medeia entre o horizonte de expectativa preexistente e a aparição de uma obra nova", que exige, para ser acolhida, a negação de experiências conhecidas ou conscientização de outras jamais expressas.

Acredita-se que esse livro, o qual exige a leitura multimodal, possui potencialidades para sensibilizar pela audição e, pela visão, "alfabetizar" o olhar desde a infância, auxiliando as crianças a se tornarem leitoras críticas. Na contemporaneidade, há muitas produções multimodais que empregam duas ou mais formas de expressão - texto, som e imagem -, cujos significados ultrapassam o limite do texto. Desse modo, a própria forma como o livro é produzido e impresso determina seu valor, penetração e atratividade. Durante a leitura dessas produções, as crianças desenvolvem sua cognição, pois precisam ativar sua memória transtextual, a fim de compreender o texto verbal, imagético e vocal em interação, além do seu suporte, enquanto se posicionam perante a realidade. Sua destinação ao terceiro ano advém de ser uma obra de extensão média que requer mais domínio do código escrito e capacidade de relacioná-lo com o visual e o musical. Este último, por sua vez, é cativante, pois confere atmosfera à leitura.

Vale destacar que a estética da sensibilidade, como princípio curricular, está presente nas Diretrizes Curriculares Nacionais, definidas pela Câmara de Educação Básica do Conselho Nacional de Educação com base no artigo $9^{\circ}$, inciso IV da Lei n. 9.394, de 20 de dezembro de 1996, Lei de Diretrizes e Bases da Educação Nacional LDB -, que aponta como uma das incumbências da União o estabelecimento, de forma colaborativa com Estados, Distrito Federal e Municípios, de "[...] competências e diretrizes para a educação infantil, o ensino fundamental e o ensino médio, que nortearão os currículos e os seus conteúdos mínimos, de modo a assegurar a formação básica comum" (BRASIL, 2013, p. 7). Em relação ao Ensino Fundamental (RESOLUÇÃO CEB $\mathrm{n}^{\mathrm{o}}$ 2/1998), o artigo $3^{\circ}$, inciso I, letra c, dispõe que “[...] os princípios estéticos da sensibilidade, da criatividade e da diversidade de manifestações artísticas e culturais" (PORTAL MEC, 2016, p. 1) serão, entre outros, norteadores das ações pedagógicas desenvolvidas nas escolas.

Pode-se observar que o mercado editorial já se organiza para o atendimento dessa diretriz, ao submeter uma obra como O lago dos cisnes (2012) ao edital do PNAIC, cuja quarta capa informa que um CD acompanha o livro com "[...] reconhecidas composições para serem apreciadas." (QUARTA CAPA, 2012 - grifo nosso). Justamente, o Acervo do PNAIC antevê uma leitura que priorize também a apreciação, pelo viés da sensibilização da criança (LITERATURA NA HORA CERTA: guia 3, 2015). Neste texto, parte-se do princípio de que estética e formação do leitor caminham juntas, assim, valoriza-se o papel da estética não somente como o de apreciação, mas de compreensão 
e crítica da realidade, sobretudo, de humanização, na acepção de Antonio Candido (1995, p. 249), como "[...] processo que confirma no homem [...] o exercício da reflexão, a aquisição do saber, a boa disposição para com o próximo, o afinamento das emoções, a capacidade de percepção da complexidade do mundo e dos seres, o cultivo do humor".

\section{Plano verbo-visual-vocal}

O vocábulo "balet", "ballet" ou "balleto" significa pequeno baile. Ana Aparecida de Almeida Sousa, em seu trabalho A prática pedagógica do Balé Clássico na educação infantil: revelando caminhos (2012), explica que o balé cortês, introduzido nos salões italianos como entretenimento, revivendo os mistérios das antigas danças de máscaras, tem sua origem na dança mourisca de personagens vestidas à moda dos Mouros.

O balé apresentado na corte possuía movimentos graciosos de cabeça, braços e tronco, bem como delicados de pernas e pés, mas que eram dificultados pelo vestuário e ornamentos muito pesados. Justifica-se, então, que, ao longo dos anos, as vestimentas tenham evoluído, em especial as saias das bailarinas, conhecidas como tutus, para conferir-lhes mais leveza, liberdade para os volteios, piruetas e pontas. No anexo "Para saber mais", ao final do livro de Yoeng (2012), informa-se uma curiosidade sobre a primeira aparição do tutu, em 1832, usado pela bailarina Marie Taglioni no balé La Sylphide. Sua aparição em cena, com a saia em forma de sino, feita de tecido branco plissado, foi avaliada como "mágica" (YOENG, 2012). Pela sua composição e manifestação artística, o balé pode ser considerado como uma arte plural que dialoga com a literatura (enredo), o teatro, a música, a dança e as artes plásticas (cenário). Assim, o balé se mostra dotado de uma história dramática representada pela dança de forma teatral, pois em atos, com o acompanhamento orquestral e os elementos de composição cenográfica. A base de sua concepção é a dança, mas esta inclui a música e o libreto.

A primeira exibição do balé $O$ lago dos cisnes recebeu inúmeras críticas relacionadas tanto à extensão de sua partitura musical, quanto à coreografia dos bailarinos. Apesar da variedade rítmica e melódica desse balé, o próprio Tchaikovsky considerou sua composição inferior à música do balé Sylvia, lançado pouco tempo depois. Conforme a bailarina Ana Botafogo (2016), Tchaikovsky ficou de tal maneira impressionado com a grandiosidade orquestral de Leo Delibes para o espetáculo Sylvia, que se sentiu envergonhado, a ponto de declarar que, se tivesse conhecido essa apresentação antes, jamais teria composto O lago dos cisnes.

O sucesso e a aceitação do público vieram com a reestreia desse balé, em 1895, dois anos após a morte de Tchaikovsky, no Teatro Mariinsky, em São Petersburgo. A nova produção foi remontada pelo coreógrafo francês Marius Petipa, que recriou as cenas do castelo (Atos I e III), ficando seu assistente russo, Lev Ivanov, responsável pelas inovações das cenas dos cisnes (Atos II e IV). No Ato III, o Pas de Deux do Cisne Negro foi criado especialmente para a bailarina Anna Sobeshchanskaya, substituindo um Pas de Six da versão original. Já em relação à partitura, esta foi reestruturada por Riccardo Drigo, diretor musical do Teatro, alterando alguns arranjos originais, com a exclusão de várias músicas e compondo novos números, entre os quais o que apresenta a variação feminina do Cisne Negro, que costuma ser creditada a Tchaikovsky (BOTAFOGO, 2016). Desde então, $O$ lago dos cisnes tem sido apresentado com variações de enfoque e novos finais, dependendo da interpretação e estilo de seu coreógrafo, passando a ser referência obrigatória no repertório do balé clássico. 
A relação entre dança, música e literatura no balé é profunda, pois se interdependem como manifestação artística. Conforme Ernesto von Rückert (2014), a voz humana é o mais primitivo instrumento musical que se manifesta pelo canto. Só em uma etapa posterior surgiu a música absoluta; dissociada de qualquer mensagem literária. Música e literatura desenvolvem-se no tempo, enquanto o balé, como objeto de percepção, se desenvolve no espaço. Assim, complementam-se em favor da Estética.

A dialogia com o balé na obra adaptada por Yoeng (2012) efetiva-se por meio das ilustrações. Na contemporaneidade, refletir sobre a imagem é necessário, pois a criança depara-se no seu cotidiano com imagens estereotipadas. Essas imagens, muitas vezes, desprovidas de encantamento, memória e imaginação não são capazes de constituir sua memória afetiva. Conforme Rui Oliveira (2008), uma das funções de uma ilustração é a de fundar uma memória afetiva na criança. Justifica-se, então, a eleição de $O$ lago dos cisnes (2012), em que a imagem é predominante em relação ao texto verbal, embora ambos se complementem. Além disso, pela representação sob a forma de um conto de fadas, sua narrativa expressa valores simbólicos que atendem às angústias internas dos pequenos leitores, como o amor suplantando dificuldades. Por sua vez, pelas representações imagéticas metalinguísticas, filiadas ao etéreo, ao onírico e ao balé, a obra tanto constitui a memória afetiva do leitor, quanto amplia seu imaginário.

O projeto gráfico de um livro, bem como as funções de suas ilustrações, revela uma intenção de leitura a partir da junção entre texto e imagem em um único objeto, ou seja, projeta um leitor implícito (ISER, 1996), instaurando o modo de ler, a sequenciação de ações e a temporalidade. Além disso, revela uma percepção de infância e de criança.

Para a análise das ricas ilustrações de Pacheco em O lago dos cisnes (2012), elegem-se, neste texto, as classificações de Luís Camargo (1998), pautadas nas funções da linguagem propostas por Jakobson. Essas imagens remetem o leitor infantil ao universo onírico próprio dos contos de fadas, bem como ao espetáculo do balé. Como representam as personagens em movimento, em um continuum, elas conduzem o olhar desse leitor para baixo e para cima, para a esquerda e à direita. Trata-se de ilustrações que exercem função narrativa, orientada para o referente, visando situar o representado, bem como suas transformações ou ações. Os traços dessas personagens em movimento conferem dinamismo ao relato. Como as ilustrações se alteram quanto à disposição, aparecendo em locais diversos da folha dupla, elas desautomatizam o olhar do leitor mirim, acostumado a ilustrações dispostas sempre na mesma localização da página. Assim, por surpreenderem na sua disposição, ampliam os horizontes de expectativas desse leitor.

As ilustrações também possuem função estética, pois compostas por bricolagens põem em relevo a forma ou configuração visual, objetivando, por meio da leitura de apreciação, sensibilizar pelas sobreposições de cores e texturas que aparecem tanto nas ilustrações das personagens e dos cenários, quanto no plano de fundo de cada cena. Essa apreciação na leitura é importante para a formação do leitor, pois significa que a estrutura de apelo da obra evoca sensações diversas, como comover, impressionar, encantar, entre outras. O encantamento captura o leitor e o motiva para o trabalho em busca da significação, concretude (ISER, 1999).

A obra em questão encanta pela atmosfera onírica de seus cenários nebulosos lago e floresta, próximos ao castelo de um príncipe -, que contaminam até mesmo as vestes dos protagonistas com transparências que sugerem efeito etéreo e diáfano à cena 
(YOENG, 2012). Essas personagens exercitam o olhar de apreciação do leitor para os detalhes ilustrados, despertam sua curiosidade para as situações inusitadas, tensas, pois dramáticas, bem como ampliam seu imaginário pela oferta de uma história voltada para o fantástico dos contos de fadas, em que há uma terrível maldição. A floresta e as figuras do vilão e de sua filha - conde Von Rothbart e Odile -, são representados com a dramaticidade das cores escuras, frias e sombrias, contrastando com os tons claros e luminosos do palácio, e dos protagonistas enamorados - Odete e o príncipe. A grandiosidade da corte é representada por figuras longilíneas que remetem ao universo do refinamento e da elegância (YOENG, 2012).

As imagens no livro são colaborativas com o texto verbal e criam jogos sequenciais coerentes e lógicos, favorecendo uma leitura lúdica e motivada. O livro é estruturado para captar a atenção de leitores que iniciam sua experiência de contato com a literatura - ainda que seja um livro igualmente agradável para todo tipo de leitor - e valoriza a oportunidade dos espaços criativos enunciativos num suporte de leitura. Suas ilustrações, pelas texturas diversas que simulam utilizar em sua composição papéis escritos na composição de cenários (p. 6, 7, 16, 17), vestimentas das personagens (p. 4, $5,13,15,17,18,19,21,22,24,25,26,31,33,36$ ), instrumentos musicais (p. 19) e montaria do príncipe (p. 8), exploram na folha dupla, na imagem, a função metalinguística. Esta função solicita do leitor uma reflexão acerca de representações em um livro. Além disso, as ilustrações indicam que as cenas, embora integrem o plano conjunto, pertencem também a outras produções escritas, com as quais dialogam: os contos de fadas e o libreto do balé de Tchaikovsky.

As cenas aparecem em imagens sangradas, como que em continuação com o universo já conhecido pelo leitor. A ausência nessas cenas de moldura convoca o olhar crítico da criança a se estender indefinidamente no universo, no caso, do fantástico, que promove encantamento. Entende-se, neste texto, fantástico, em consonância com Jacqueline Held (1980, p. 23), como o que se opõe ao real, “[...] criado pelo espírito, pela fantasia" de um autor, o qual exerce pela palavra sua potencialidade imaginativa na produção de seres irreais e cenários surpreendentes, dispostos em um mundo autônomo. Pode-se notar pelo enredo da obra adaptada, sob a forma de conto de fadas, a manutenção dos mesmos temas - amor eterno, vingança, maldição -; a mesma temporalidade que evoca o sonho; o mesmo espaço cortês e percurso narrativo. Há, então, uma paráfrase estrutural com o balé no plano narrativo e temático, pois mantém-se no texto ilustrado a atmosfera suntuosa e dramática do espetáculo.

A inovação da obra de Yoeng (2012) recai no emprego do hibridismo de gêneros textuais, no emprego de imagens sangradas na ilustração e na materialidade do livro. Nota-se que a suntuosidade é assegurada pela capa dura e dimensão do próprio livro em formato amplo com $23 \mathrm{~cm}$ de largura por $30,5 \mathrm{~cm}$ de altura quando fechado. Pela textura resistente de seu papel, percebe-se que foi planejado para ser manuseado pelo pequeno leitor. Suas folhas duplas ilustradas promovem a sensação de "mergulho" na história, de espetáculo disposto ao olhar, dialogando com o balé. No livro, antevê-se a confluência de linguagens verbal e imagética, enriquecidas pela vocal: a audição das composições de Tchaikovsky.

Sua abertura, folhas de guarda, sugere uma história solar, com a apresentação de um sol estilizado com dezesseis raios retos e dezesseis ondulantes intercalados, os quais circundam um rosto personificado e sobressaltado ao centro. Suas cores e textura 
conotam que fora moldado em argila. Esse sol aparece em fundo composto por texturas nas cores mostarda, amarela e ocre. Essa ilustração remete ao deus sol dos antigos incas, conhecido também como Sol de Maio, que pode ser visto em bandeiras e escudos da Argentina e do Uruguai ${ }^{1}$. Pela leitura, nota-se que, apesar do sol estilizado, trata-se de uma história cujas peripécias ocorrem em cenários lúgubres, que remetem à madrugada, ao período intermediário, entre noturno e diurno. Assim, seu enredo dialoga com esse sol, alegoria de impedimento entre o amor de Odete e o príncipe, portanto em sua potência destruidora - que, conforme Jean Chevalier e Alain Gheerbrant (1999, p. 836), representa "[...] o princípio da seca, à qual se opõe a chuva fecundadora."-, pelo viés paródico, conotando que o amor dos protagonistas vicejará, apesar da maldição que, proferida pelo conde Von Rothbart, produz obstáculos. Justifica-se, então, que o inquietante rosto desse sol demonstre, diante da subversão, sobressalto.

A própria capa do livro de Yoeng (2012), com uma jovem de cabelos presos, com um longo vestido branco, cuja saia remete a sobreposições de tecidos diáfanos, com o rosto parcialmente encoberto, do qual se vê os olhos voltados para o vazio, abraçada a um cisne de asas abertas, é inquietante. Essa capa dá prosseguimento à ilustração da quarta, em que se vê três cisnes em um nebuloso lago, os quais se voltam para uma jovem. Seu texto com fins publicitários informa que a jovem Odete é vítima de um feitiço que, durante o dia, a mantém na forma de um cisne e, à noite, permite que retome a forma humana. Sua maldição terá fim quando conhecer o verdadeiro amor. No transcorrer da narrativa, nota-se que, somente após a meia-noite, Odete toma sua forma humana. As folhas de rosto apresentam ao centro a imagem de dois cisnes nadando em um lago azulado que projeta seus reflexos. Na folha de abertura vê-se uma revoada de várias dessas aves na direção inversa - à esquerda - ao virar de páginas, conotando que fogem de algo ou alguém. Durante a leitura, pode-se deduzir que fogem dos caçadores e, principalmente, do conde feiticeiro.

O livro estabelece no plano verbal e imagético dialogia, bem como comunicabilidade. O diálogo com o teatro avulta no texto que antecede o enredo - "Esta história aconteceu em um tempo encantado, quando a magia era poderosa. Por meio de encantos, humanos podiam ser transformados em animais e animais, em humanos." (YOENG, 2012, p. 4) -, e na folha dupla de abertura da obra, em que se apresentam informações sobre cada uma das personagens, acompanhadas de suas características e respectivas ilustrações. As ilustrações dessas personagens que, em sua maioria pertencem à nobreza - as masculinas, inclusive, detêm títulos: Príncipe Siegfried e Conde Von Rothbart -, também, dialogam com os contos de fadas, assim como a clássica fórmula de abertura da história: "Era uma vez, em um reino muito distante, [...]." (YOENG, 2012, p. 6, grifo nosso). O diálogo com o espetáculo do balé e com a música pode ser visto, por meio da dramaticidade das ilustrações (YOENG, 2012, p. 4-5) e das indicações por escrito do número de cada ato da história e da faixa do $\mathrm{CD}$, bem como da música, que o acompanha. Pode-se notar na abertura do primeiro ato, no canto esquerdo da folha dupla, a ilustração discreta de um $\mathrm{CD}$, seguido de uma barra vertical que indica logo após: "FAIXA I/Ato I - Valsa n" 2" (YOENG, 2012, p. 6).

\footnotetext{
1 As bandeiras da Argentina e do Uruguai podem ser vistas, respectivamente em: $<$ www.estudopratico.com.br/significado-da-bandeira-da-argentina/ $>$; $<$ www.uruguai.com/informacao-aoviajante/bandeira-do-uruguai.html>.
} 
A comunicabilidade com o leitor implícito se estabelece na sucinta abertura do enredo: "Era uma vez, em um reino muito distante, um príncipe chamado Sigfried e a rainha, sua mãe." (YOENG, 2012, p. 6). Percebe-se que a interação com o leitor é suscitada pelo vazio, provocado pela elipse do verbo associado à existência da rainha. Assim, para que haja interpretação, o leitor precisa completar a lacuna. Esta estratégia discursiva do autor, por sua vez, confere velocidade ao seu texto e é agradável ao leitor que se sente considerado no relato. Como essa abertura, além da elipse, apresenta outros recursos estilísticos, tais como aliteração em "p" e assonância em "i", "o" e "e", para acentuar os vocábulos príncipe e palácio; anástrofe (inversão sutil); personificação e sinestesia, permitindo desautomatizar as concepções do leitor sobre os usos da língua, além de surpreendê-lo pelo aumento da expressividade da mensagem: "Pronto para festejar o vigésimo primeiro aniversário do príncipe, o palácio estava enfeitado com as mais belas flores e exalando os mais deliciosos aromas." (YOENG, 2012, p. 5, destaques gráficos nossos).

A obra trata da temática trovadoresca do amor impossível, mas eterno, e do casamento por conveniência. Além disso, destaca a maldição sob a qual vive a bela Odete, suscitando engajamento do leitor e sua adesão à trama, por meio da questão que a ele se dirige: "Quem poderia salvá-la?" (YOENG, 2012, p. 4). A opção pelos nomes muito próximos das jovens protagonistas - Odete e Odile -, e pelo afastamento na sua caracterização, pois a primeira é loira e usa roupas brancas; e a segunda morena, sempre com roupas escuras, dialoga com a lenda medieval Tristão e Isolda ${ }^{2}$. Nesta história, há mulheres muito diferentes, que se envolvem também em conflitos que as unem. Seus nomes possuem apenas variações nos epítetos, como: Isolda, a loura; Isolda, das brancas mãos; Isolda, a feiticeira.

No plano imagético, pode-se observar, pela postura corporal dessas mulheres esguias e longilíneas, com os braços projetados dramaticamente para trás, rosto voltado em direção diversa ao do corpo, de vestimentas longas - compostas por sobreposições de texturas, elementos e flores -, e golas altas, rodeadas de tecido translúcido, a dialogia com o balé (YOENG, 2012), mas também com os quadros do simbolista Gustav Klimt (18621918). Com este quadro, nota-se também a dialogia na cena em que os protagonistas enamorados - Odete e Siegfried - quase se beijando. Esse beijo não acontece, pois o encontro é breve, pela aproximação do sol que transformará Odete em cisne. Sua explicação está no texto verbal: "Sob o luar, Siegfried e Odete olharam-se com carinho. Mas esse momento foi breve, pois o sol logo nasceria." (YOENG, 2012, p. 14). Essa cena dialoga, mais especificamente, com o quadro $O$ beijo, de Klimt, produzido em 1907 (O LIVRO DA ARTE, 1997, p. 252), no qual as representações surpreendem o olhar pelo inusitado da cena, das cores e texturas. Pode-se perceber, então, que as ilustrações são dialógicas, colaborativas do texto verbal e surpreendentes. Justamente por isto, podem romper com os conceitos prévios do leitor habituado a ilustrações óbvias.

As ilustrações das antípodas - Odete e Odile -, pela expressão facial, se opõem. A primeira, vestida de cores claras, está entristecida e desanimada. A segunda, com cores escuras, possui feições duras e enérgicas, conotando aborrecimento ou desaprovação de algo. Essa expressividade manifesta no rosto das personagens, pela capacidade de

\footnotetext{
${ }^{2}$ Essa lenda possui inúmeras adaptações contemporâneas, vale conhecer a que compõe o acervo do PNBE 2013 e pode ser encontrada nas Salas de Leitura e/ou bibliotecas das escolas públicas: GOMES, Helena. Tristão e Isolda. 2. reimpr. Ilustr. Renato Alarcão. São Paulo: Berlendis \& Vertecchia, 2014.
} 
expressar seus sentimentos, exerce função expressiva, direcionada ao emissor que tanto pode se identificar com elas, quanto as repudiar.

A abertura oficial da obra, que tem início no "Era uma vez", situa o primeiro ato da história já no conflito, pois a rainha, preocupada com o futuro do príncipe, determina que, na noite seguinte, durante um baile, ele escolha sua futura esposa. Essa decisão real gera ansiedade entre nobres e aldeões, pois "Todos queriam levar suas filhas ao palácio para comemorar o aniversário do príncipe.” (YOENG, 2012, p. 6). O baile possui, assim, dupla função: assegurar continuidade da família real no trono e celebrar o $21^{\circ}$ aniversário do príncipe. Associa-se a esse ato a "Valsa no 2" (faixa 1 do $\mathrm{CD}$ ), própria para a dança entre pares nos grandes bailes. A audição pelo leitor pode evocar a grandiosidade do baile real, mas também a dramaticidade, pois o príncipe está em conflito. Sabe-se, na cena seguinte, que ele sonha em se casar por amor e não por convenção. As ilustrações em folha dupla dessa cena do $1^{\circ}$ ato não só colaboram com o texto verbal, como avançam em significação em relação a este, pois revelam a rainha anunciando sua intenção aos seus súditos (YOENG, 2012). Atrás deles, o príncipe olha diretamente para sua mãe com expressão de desaprovação, mas isto não consta no texto verbal. A metalinguagem avulta na composição de alguns súditos, dos quais só se vê o contorno, como que recortado de folhas antigas e amareladas, com escritos diversos, e na arquitetura gótica que remete aos séculos XI e XII na Europa, em que se vê na fachada da estrutura, sob a qual se abrigam rainha e súditos, bricolagens de recortes de textos antigos e amarelados.

Nota-se, nessa cena ainda, que as lacunas do texto verbal são preenchidas pelo imagético (YOENG, 2012). Mas este também é composto por elas, pela ausência de forma humana e presença de recortes em seu formato, dialogando com os metalinguísticos quadros de René Magritte (1898-1967) e seus efeitos de estranhamento que levam à reflexão sobre a construção pictórica. Já a atmosfera produzida nessa cena é dramática e evoca uma montagem teatral, pelos recursos metalinguísticos, pelo Sol de Maio ao fundo. Além disso, pela caricatura das personagens com estatura elevada, longilíneas e esguias, denota-se que pertencem a um universo grandioso - o dos sonhos - bem diverso do mundano. A dramaticidade é intensificada com a composição musical primorosa de Tchaikovsky.

O segundo ato possui quatro cenas. A primeira tem início na adesão do príncipe a uma caçada proposta pelos seus amigos para animá-lo, em que usará seu novo conjunto de arco e flecha. Surge uma revoada de cisnes que é seguida pelos cavaleiros. Essa cena associa-se à composição "Cena $\mathrm{n}^{\mathrm{o}} 1$ " (faixa 2), que evoca, inicialmente, tristeza e abatimento, mas pela dramaticidade, também o risco da caçada. Como seu cavalo é composto pela ausência, apenas, pelo contorno, como que recortado de um texto muito antigo, mantém-se a atmosfera teatral (YOENG, 2012) e a dialogia com os metalinguísticos quadros de Magritte, permeados de lacunas imagéticas.

$\mathrm{Na}$ segunda cena, enquanto os amigos do príncipe prosseguem com a cavalgada, ele se dirige a um lago, onde vê vários cisnes. No momento em que mira uma das aves, um clarão as cerca e elas se transformam em belíssimas moças. Uma coruja assiste a tudo do alto de um galho: era o feiticeiro (YOENG, 2012). Associa-se a esta cena a composição "Dança dos pequenos cisnes" (faixa 3), seu ritmo delicado, mas veloz, sugere uma dança intensa. Vale destacar a representação da metamorfose das moças, que dialoga com o balé. Assim, elas se apresentam com as pernas e os braços em passo de dança, mas ainda 
com o pescoço e a cabeça de cisne (YOENG, 2012), o que cativa pelo estranhamento o pequeno e jovem leitor.

$\mathrm{Na}$ terceira cena, uma delas se destaca pela beleza e carisma: Odete. Indagada pelo príncipe, ela o informa da maldição. Diante disto, ele lhe promete eterno amor, visando a quebrar o feitiço. Contudo, este não se desfaz somente com a jura do príncipe. Assim, como no romance cortês e no conto de fadas, ele deve provar seu valor e sua persistência na promessa. A representação de Odete, nessa cena (YOENG, 2012), dialoga com o balé, pois ela aparece dançando na ponta dos pés de forma dramática, com os braços erguidos e jogados para trás, e a cabeça inclinada, conotando o sofrimento em que vive. Sua disposição entre árvores que encobrem parcialmente seu vestido e seu corpo, suscitando o olhar de concretude - que busca comunicabilidade, sentido, por meio do resgate pelo leitor implícito da coerência do texto que os vazios interromperam -, também dialoga com os quadros de Magritte, em especial, Carta Branca, de 1965 (PAQUET, 2000).

$\mathrm{Na}$ cena final deste ato, nota-se que o príncipe, em dialogia com o quadro "Sobre a cidade" (O LIVRO DA ARTE, 1996), de 1915, de Marc Chagall (1887-1985), em que prevalecem as transparências e o viés onírico, flutua na direção de Odete, quase a beijando, em sua jura em punir o culpado (YOENG, 2012). Ela o alerta para não o fazer, pois se o feiticeiro morrer, a maldição não será quebrada. Associa-se à cena a composição "Dança dos Cisnes" (faixa 4), que evoca, pela delicadeza da harpa, a tristeza dos amantes diante da constatação de que o feitiço não se quebrara. Ele pede à Odete para ir ao baile na noite seguinte, quando a anunciará como sua noiva. O dia amanhece e os cisnes partem.

Tem início o terceiro ato - clímax da história -, com dez cenas, ao qual se associa a composição "Dança Húngura $\mathrm{n}^{\circ}$ 20" (faixa 5), que remete ao clima alegre e grandioso de baile palaciano (YOENG, 2012). O príncipe dança com todas as jovens da festa, mas Odete não chega (cena 1). As trombetas anunciam, então, a chegada do conde e de sua filha Odile que, graças às artes feiticeiras do pai, muito se assemelha a Odete, embora use vestido em tons escuros (cena 2) (YOENG, 2012). Como o príncipe não percebe o engodo, ele dança com Odile, que dissimula sua identidade (cena 3) (YOENG, 2012). Ele, então, a anuncia como noiva. Uma risada maligna invade o local (cena 4) (YOENG, 2012).

Nessa cena, embora não esteja no plano verbal, nota-se no imagético que Odete, entre pilares do castelo, aproxima-se e vê o príncipe abraçado à Odile. Diante disto, Odete, com seu belo vestido branco, chora apoiada em uma janela. O príncipe olha as duas moças, mas sem compreender. Quando percebe que fora ludibriado, Odete já fugira (cena 5) (YOENG, 2012). A jovem, dramaticamente, pensa em tirar sua vida, atirando-se ao lago, pois imagina que está perdida. Suas amigas a impedem (cena 6) (YOENG, 2012). O príncipe corre para o lago, mas precisa lutar com tempestades e ventanias causadas pelo feiticeiro para impedi-lo de atingir seu intento (cena 7) (YOENG, 2012). Mesmo assim, ele a tudo enfrenta, encontra Odete e pede seu perdão (YOENG, 2012). Ela imagina que agora não há mais como findar a maldição. Ele decide segui-la então (cena 8). Mas o feiticeiro faz com que surja uma imensa onda nas águas do lago, a qual engole Odete. Ele não supunha que o príncipe se atiraria nas águas para salvá-la, mas ele o faz, revelando, então, seu amor verdadeiro, que abdica da própria vida se for necessário (cena 9) (YOENG, 2012). A constatação da existência desse amor destrói o conde e todos os feitiços desaparecem (cena 10) (YOENG, 2012). 
O último ato, com uma única cena, inicia-se. Nesta, o príncipe e sua amada voltam ao palácio, casam e vivem "[...] felizes para sempre." (YOENG, 2012). Associa-se a essa cena a composição "Cena Final n ${ }^{\circ} 29$ " que, pela intensidade, seguida de profunda delicadeza melódica, evoca os desfechos felizes resultantes de drama intenso. Talvez, os jovens leitores reconheçam parte dessa composição, se a associarem à trilha sonora dos filmes da saga Harry Potter, de J. K. Rowling.

\section{Considerações finais}

Pelo exposto, pode-se perceber que a obra requer apreciação em um primeiro momento, a qual pode ser feita pela leitura espontânea, no manuseio direto do livro e na audição das composições. Mas em um segundo momento, visando à formação do leitor estético, faz-se necessária uma mediação que explicite as dialogias que se estabelecem entre a obra de Yoeng (2012) com o teatro, o balé e os contos de fadas. Além disso, das ilustrações com o espetáculo do balé e os quadros de Magritte, Chagall e Klimt.

Pela análise da obra, pode-se notar que possui projeto gráfico-editorial bem elaborado e instaura lacunas em seu texto verbal que serão preenchidas pela leitura do texto imagético. Este, por sua vez, possui lacunas que estabelecem comunicabilidade com o leitor e diálogo com o texto verbal. Sua linguagem é adequada ao leitor em formação, bem como seus recursos imagéticos asseguram o teor dramático à história. Em seu desenvolvimento, a dialogia entre o balé e o enredo se efetiva de forma bem-sucedida. Além disso, essa dialogia, pela instauração de lacunas no texto, ao convocar a projeção imagética do leitor em seu preenchimento, assegura a comunicabilidade, tornando a obra atraente na leitura, pois considera seu leitor implícito como inteligente e interativo.

Por meio da mediação de $O$ lago dos cisnes, pode-se assegurar a construção de conhecimentos e ampliação dos horizontes de expectativa dos pequenos leitores, revelando-lhes que as ilustrações não são mero apoio para o texto verbal. Pela leitura, esses leitores podem notar cenas que, embora coerentes com o enredo, avançam em relação à significação deste, inclusive, complementando-o.

Pelo exposto, é válida a hipótese de que Yoeng (2012) realiza sua adaptação, facultando ao leitor contato com um texto atraente, capaz de conduzi-lo à reflexão e ampliação de seus conhecimentos, por meio do resgate da memória cultural. Pela leitura e mediação dessa obra, o leitor apropria-se de uma produção clássica que representa sua herança, seu patrimônio cultural.

\section{REFERÊNCIAS}

BAKHTIN, M. Estética da criação verbal. Tradução de Maria Ermantina Galvão. 3. ed. São Paulo: Martins Fontes, 2000.

BRASIL. Diretrizes Curriculares Nacionais Gerais da Educação Básica. Ministério da Educação. Secretaria de Educação Básica. Diretoria de Currículos e Educação Integral. Brasília: MEC, SEB, DICEI, 2013. Disponível em: $<$ http://www.cp2.g12.br/alunos/leis/lei_diretrizes_bases.htm>. Acesso em: 06 jul. 2016.

BOTAFOGO, A. Blog de dança. Disponível em: <http://lojaanabotafogo.com.br/o-lagodos-cisnes>. Acesso em: 02 jul. 2016. 
CAMARGO, L. H. de. Poesia infantil e ilustração: estudo sobre Ou isto ou aquilo de Cecília Meireles. 1998. 214 f. Dissertação (Mestrado em Teoria Literária) - Instituto de Estudos da Linguagem, Universidade Estadual de Campinas, Campinas, 1998.

CANDIDO, A. O direito à literatura. In: Vários escritos. 3. ed. rev. e ampl. São

Paulo: Duas Cidades, 1995. p. 235-263.

CHEVALIER, J.; GHEERBRANT, A. Dicionário de símbolos: mitos, costumes, gestos, formas, figuras, cores, números. Colaboração de André Barault et al., coordenação de Carlos Sussekind, tradução de Vera da Costa e Silva et al. 14. ed. Rio de Janeiro: José Olympio, 1999.

DIÁRIO OFICIAL DA UNIÃO. Disponível em: <file://C:/Users/Eliane/Downloads/resultado_avaliacao_pedagogica_pnld_alfabetizaca o_idade_certa_2014.pdf $>$. Acesso em: 05 jul. 2016.

FTD EDUCAÇÃO. Disponível em: $<$ http://www.ftd.com.br/detalhes/?id=5318>. Acesso em: 05 jul. 2016.

HELD, J. O imaginário no poder: as crianças e a literatura fantástica. Tradução de Carlos Rizzi, São Paulo: Summus, 1980.

ISER, W. O ato da leitura: uma teoria do efeito estético. Tradução de Johannes Kretschmer. v. 1. São Paulo: Ed. 34, 1996.

$O$ ato da leitura: uma teoria do efeito estético. Tradução de Johannes Kretschmer. v. 2. São Paulo: Ed. 34, 1999.

JAUSS, H. R. A história da literatura como provocação à teoria literária. Tradução de Sérgio Tellaroli. São Paulo: Ática, 1994.

LINDEN, S. V. der. Para ler o livro ilustrado. Tradução de Dorothée de Bruchard. São Paulo: Cosac Naify, 2011.

LITERATURA NA HORA CERTA: guia 3: $3^{\circ}$ ano do ensino fundamental: PNLD/PNAIC: alfabetização na idade certa 2015. Ministério da Educação, Secretaria de Educação Básica. - Brasília: MEC/SEB, 2015. Disponível em: $<$ http://portal.mec.gov.br/index.php?option=com_docman\&view=download\&alias $=176$ 29-guia-03-literatura-hora-certa\&category_slug=junho-2015-pdf\&Itemid=30192>.

Acesso em: 05 jul. 2016.

O LIVRO DA ARTE. Tradução de Monica Stahel. São Paulo: Martins Fontes, 1997.

OLIVEIRA, R. de. Breve histórico da ilustração no livro infantil e juvenil. In: OLIVEIRA, I. de (Org.). O que é qualidade em ilustração no livro infantil e juvenil: com a palavra o ilustrador. São Paulo: DCL, 2008. p. 13-47.

PACTO NACIONAL PELA ALFABETIZAÇÃO NA IDADE CERTA. Disponível em: $<$ http://pacto.mec.gov.br/noticias/134-adesao-2016>. Acesso em: 05 jul. 2016.

PAQUET, M. Magritte: o pensamento tornado visível. Tradução de Lucília Filipe. Köln: Taschen, 2000.

PORTAL MEC. Resolução $\mathrm{n}^{0}$ 7, de 14 de dezembro de 2010. Disponível em: $<$ http://portal.mec.gov.br/dmdocuments/rceb007_10.pdf $>$. Acesso em: 05 jul. 2016. 
- Resolução SEB $\mathrm{n}^{\circ}$ 2, de 07 de abril de 1998. Disponível em:

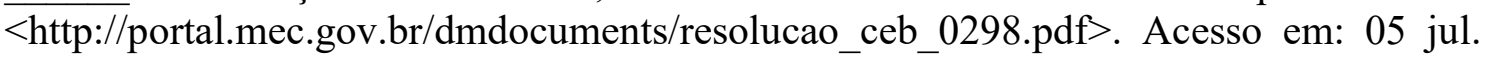
2016.

RÜCKERT, E. von. Música e literatura. Disponível em: $<$ http://www.ruckert.pro.br/texts/musicaeliteratura.pdf>. Acesso em: 19 ago. 2014.

SOUZA, A. A. A. de. A prática pedagógica do Balé Clássico na educação infantil: revelando caminhos. Várzea Paulista: Fontoura, 2012.

YOENG, L. Ji. (Adapt.). O lago dos cisnes: Pyotr Ilyich Tchaikovsky. Ilustração de Gabriel Pacheco. Tradução de Heloisa Prieto. São Paulo: FTD, 2012.

Recebido em: 25/08/2016

Aprovado em: 29/11/2016 